\title{
Мукомольные свойства озимых сортов зерна тритикале
}

\author{
Кандроков Роман Хажсетович \\ ФГБОУ ВО «Московский государственный университет пищевых производств» \\ Адрес: 125080, г. Москва, Волоколамское шоссе, д. 11. \\ E-mail: nart132007@mail.ru \\ Панкратов Георгий Несторович \\ ВНИИЗ - филиал ФГБНУ «Федеральный научный \\ центр пищевых систем им. В.М. Горбатова» РАН \\ Адрес: 127434, Москва, ул. Дмитровское шоссе, д. 11. \\ E-mail: pankratof.gn@yandex.ru \\ Рындин Александр Алексеевич \\ ФГБОУ ВО «Московский государственный университет пищевых производств» \\ Адрес: 125080, г. Москва, Волоколамское шоссе, д. 11. \\ E-mail:aleksandr-ryndin@rambler.ru \\ Конорев Павел Матвеевич \\ Российский государственный аграрный университет - \\ МСХА имени К.А. Тимирязева \\ Адрес: 127434, г. Москва, ул. Тимирязевская, д. 49. \\ E-mail:konorev@rgau-msha.ru
}

\begin{abstract}
Использование в различных отраслях пищевой и перерабатывающей промышленности продуктов переработки нетрадиционной зерновой культуры - тритикале в настоящее время привлекает все большее внимание, как производителей зерна, так ученых в нашей стране и за рубежом. Обусловлено это обстоятельство увеличением посевных площадей, созданием озимых сортов зерна тритикале, включенных в реестр сортов, многочисленными исследованиями технологического, биохимического и биологического потенциала зерна тритикале. В связи с этим целью наших исследований стало определение потенциальных мукомольных свойств новых сортов зерна озимого тритикале как сырья для производства тритикалевой муки различного назначения. Объектом исследований потенциальных мукомольных свойств озимого зерна тритикале являются 5 новых сортов - Консул, Капрал, Ацтек, Корнет и Топаз. Определение потенциальных мукомольных свойств новых сортов тритикале проводили на лабораторных мельницах РСА-4 с нарезными и гладкими, микрошероховатыми вальцами. На всех драных системах и вымольной системе использовали рифленые вальцы с расположением рифлей острие по острию, а на размольных системам использовали вальцы с гладкой микрошероховатой поверхностью. Установлено наличие 3-х этапов формирования тритикалевой муки, что достаточно четко видно из графиков кумулятивных кривых. Первый участок - измельчение центральной части эндосперма и включает в себя 3-4 потока. Далее идет второй участок, на котором происходит измельчение эндосперма и периферийной части, включающий в себя 3-4 потока. На третьем, заключительном участке происходит вымол оболочек и включает в себя 3-4 потока. Общий выход тритикалевой муки из сорта Консул составил 73,8 \% зольностью 0,80 \%, из сорта Капрал составил 77,2 \% зольностью 0,94 \%, из сорта Ацтек составил 76,4 \% зольностью 0,71 \%, из сорта Корнет составил 75,6 \% зольностью 0,82 \%, из сорта Топаз составил 73,2 \% зольностью 0,73 \%. Наилучшими мукомольными свойствами из представленных образцов тритикале обладает сорт Ацтек выход тритикалевой муки высшего сорта Т-60 из которого составил 59,2\% с зольностью 0,59 \%.
\end{abstract}

Ключевые слова: озимое тритикале, мукомольные свойства, мука, выход, белизна, зольность, кумулятивная кривая

\section{Введение}

В стратегии развития пищевой и перерабатывающей промышленности до 2030 года предусмотрен переход этих отраслей к модели инновационного развития. Одними из приоритетных направлений долгосрочного периода являются: разработка биотехнологий, позволяющих расширить выработку продуктов нового поколения, в том числе хлебобулочной продукции, с заданными технологическими 
и функциональными свойствами, переход к ресурсосберегающим технологиям, позволяющим вовлечь в хозяйственный оборот вторичные сырьевые ресурсы и обеспечить глубокую переработку сырья.

Тритикале - сравнительно новая сельскохозяйственная культура, используемая на пищевые и кормовые цели в Российской Федерации. В Государственный реестр селекционных достижений, допущенных к использованию в России (2020 г.), внесено 90 сортов озимого тритикале и 18 сортов ярового тритикале. Для сравнения в 2008 г. было внесено 45 сортов озимого тритикале и 3 сорта ярового тритикале, таким образом за последние 10 лет возросло более чем в 2 раза. Все новые сорта рекомендованы для использования на продовольственные цели.

Биопотенциал зерна тритикале в первую очередь зависит от сортовых особенностей и условий выращивания (Мелешкина и др., 2018). Пищевая ценность зерна оценивается высоким содержанием белка, незаменимых аминокислот, сбалансированностью аминокислотного состава (Мелешкина и др., 2018). Биологическая ценность продуктов переработки зерна тритикале обусловлена преобладанием водо- и соле- растворимых фракций белка и, как следствие, более высокой степенью усвоения белков тритикале, а также наличием витаминов, макро- и микроэлементов (Витол, Мелешкина, Кандроков, Вережникова, \& Карпиленко, 2016; Витол, Мелешкина, Кандроков, Вережникова, \& Карпиленко, 2017).

За последние 10 лет большие исследования по изучению технологических свойств различных сортов зерна тритикале проведены во ВНИИЗ - филиале ФГБНУ «Федеральный научный центр пищевых систем им. В.М. Горбатова» РАН. Эти исследования легли в основу разработанных и введенных в действие межгосударственных стандартов на пищевое зерно тритикале, на тритикалевую муку и тритикалевую крупу (Кандроков, Стариченков, \& Штейнберг, 2015; Витол, Мелешкина, \& Кандроков, 2016; Панкратов, Мелешкина, Кандроков, \& Витол, 2016; Панкратов, Кандроков, \& Щербакова, 2016; Кандроков, Панкратов, 2017; Meleshkina, Pankratov, Vitol, Kandrokov, \& Tulyakov, 2017; Kandrokov, Pankratov, Meleshkina, Vitol, \& Tulyakov, 2019).

Во ВНИИ хлебопекарной промышленности и Воронежском государственном университете инженерных технологий разработаны научные основы и технологические аспекты применения зерна тритикале в производстве хлебобулочных изделий (Карчевская, Дремучева, \& Грабовец, 2013; Магомедов, Малютина, \& Шапкарина, 2016).
В Кубанском государственном аграрном университете провели комплексные исследования технологических свойств зерна тритикале (Сокол, 2014).

Во ВНИИ Крахмалопродуктов разработали технологию производства сухого корма из вторичных продуктов переработки зерна тритикале на крахмал (Андреев, Носовская, Адикаева, Некрасова, \& Гольдштейн, 2016).

Исследования зарубежных ученых, проведенные за последние годы, в основном, связаны с биологией видов тритикале и биобезопасностью при его росте и развитии, происхождением тритикале, промышленным производством

тритикале и его конкурентоспособностью с пшеницей, геномикой и биотехнологией зерна тритикале и продуктов его переработки (De Laethauwer, Reheul, De Riek, \& Haesaert, 2012; Bona, et al., 2013; Dennett, Cooper, \& Trethowan, 2013; Blum, 2014; He, et al., 2014; Dennett \& Trethowan, 2013).

Цель данного исследования - определение потенциальных мукомольных свойств сортов зерна озимого тритикале как сырья для производства тритикалевой муки различного назначения.

\section{Материалы и методы исследования}

Исследования проведены в лаборатории «Технология и техника мукомольного производства» ВНИИЗ - филиала ФГБНУ «Федеральный научный центр пищевых систем им. В.М. Горбатова» РАН. Объекты исследований - сорта озимого тритикале (Консул, Капрал, Ацтек, Корнет, Топаз) селекции ФГБНУ «Федеральный Ростовский аграрный научный центр», урожая 2019 года. Определение потенциальных мукомольных свойств зерна проведено по разработанной лабораторной технологической схеме, включающей в себя 4 драных, 5-6 размольных и 1 вымольную систему (Кандроков, Стариченков, \& Штейнберг, 2015). Измельчение осуществляли на размоло-сортирующих агрегатах РСА-4 с нарезными и гладкими, микрошероховатыми вальцами.

На всех драных системах и вымольной системе использовали рифленые вальцы с расположением рифлей острие по острию, а на размольных системам использовали вальцы с гладкой микрошероховатой поверхностью.

В качестве гидротермической обработки применяли способ холодного кондиционирования, как 
наиболее распространенный и наиболее дешевый. Увлажнение проводили до конечной влажности 15,5-16 \% и отволаживали в течение 10 часов.

Режимы и параметры измельчения на вальцовых станках для всех сортов озимого тритикале оставались неизменными. Просеивание промежуточных продуктов измельчения проводили на лабораторном рассеве.

Зольность продуктов переработки новых сортов зерна тритикале определяли по ГОСТ 27494-2016¹, белизну по ГОСТ 26361-2013², влажность по ГОСТ $13586.5-2015^{3}$.

\section{Результаты и их обсуждение}

На первом этапе исследований провели лабораторные помолы представленных образцов зерна тритикале с определением выхода, влажности, белизны и зольности каждого отдельного потока тритикалевой муки. Всего потоков тритикалевой муки получилось от 11 до 12.
Полученные результаты лабораторного помола по определению потенциальных мукомольных свойств исходного образца зерна тритикале сорта Консул представлены в Таблице 1.

Полученные результаты лабораторного помола по определению потенциальных мукомольных свойств исходного образца зерна тритикале сорта Капрал представлены в Таблице 2.

Полученные результаты лабораторного помола по определению потенциальных мукомольных свойств исходного образца зерна тритикале сорта Ацтек представлены в Таблице 3.

Полученные результаты лабораторного помола по определению потенциальных мукомольных свойств исходного образца зерна тритикале сорта Корнет представлены в Таблице 4.

Полученные результаты лабораторного помола по определению потенциальных мукомольных свойств исходного образца зерна тритикале сорта Топаз представлены в Таблице 5 .

Таблица 1

Выход, белизна и зольность продуктов размола зерна сорта Консул

\begin{tabular}{|c|c|c|c|c|c|}
\hline $\begin{array}{c}\text { Выход муки } \\
\text { и отрубей по системам }\end{array}$ & Выход, \% & Влажность, \% & $\begin{array}{l}\text { Белизна, } \\
\text { ед. пр. }\end{array}$ & Зольность, \% & $\begin{array}{c}\text { Выход× } \\
\text { Зольность }\end{array}$ \\
\hline I дранная & 8,8 & 15,8 & 48,0 & 0,83 & 7,30 \\
\hline II дранная & 6,1 & 16,2 & 58,4 & 0,68 & 4,15 \\
\hline III дранная & 6,1 & 15,8 & 53,0 & 0,79 & 4,82 \\
\hline IV дранная & 3,1 & 15,0 & 41,6 & 1,1 & 3,41 \\
\hline 1 размольная & 16,3 & 15,6 & 58,7 & 0,59 & 9,62 \\
\hline 2 размольная & 14,3 & 15,2 & 60,3 & 0,63 & 9,01 \\
\hline 3 размольная & 5,5 & 15,2 & 57,3 & 0,67 & 3,69 \\
\hline 4 размольная & 3,8 & 14,4 & 48,0 & 0,79 & 3,00 \\
\hline 5 размольная & 2,7 & 14,8 & 51,6 & 0,82 & 2,21 \\
\hline 6 размольная & 1,0 & 14,6 & 11,8 & 2,12 & 2,12 \\
\hline 7 размольная & 6,1 & 14,4 & 4,3 & 1,55 & 9,46 \\
\hline$\sum$ Муки & 73,8 & & & $\mathrm{Zcp}=0,80$ & 58,78 \\
\hline Отруби 1 & 18,0 & 15,4 & - & 5,0 & 90 \\
\hline Отруби 2 & 8,2 & 13,6 & - & 4,63 & 37,97 \\
\hline$\sum$ Отрубей & 26,2 & & - & $\mathrm{Zcp}=4,88$ & 127,97 \\
\hline Всего: & 100 & & & $\begin{array}{l}\text { Ср. взвеш. } \\
=1,87 \%\end{array}$ & \\
\hline
\end{tabular}

ГОСТ 27494-2016. (2019). Межгосударственный стандарт. Мука и отруби. Методы определения зольности. М.: Стандартинформ.

2 ГОСТ 26361-2013. (2014). Межгосударственный стандарт. Мука. Метод определения белизны. М.: Стандартинформ.

3 ГОСТ 13586.5-2015. (2019). Межгосударственный стандарт. Мука. Метод определения влажности. М.: Стандартинформ. 
Таблица 2

Выход, белизна и зольность продуктов размола зерна сорта Капрал

\begin{tabular}{|c|c|c|c|c|c|}
\hline $\begin{array}{c}\text { Выход муки } \\
\text { и отрубей по системам }\end{array}$ & Выход, \% & Влажность, \% & Белизна, ед. пр. & Зольность, \% & $\begin{array}{c}\text { Выход× } \\
\text { зольность }\end{array}$ \\
\hline I дранная & 4,8 & 14,2 & 30,8 & 0,96 & 4,61 \\
\hline II дранная & 3,2 & 14,4 & 44,5 & 0,97 & 3,10 \\
\hline III дранная & 6,0 & 14,2 & 47,9 & 1,0 & 6,0 \\
\hline IV дранная & 1,6 & 13,4 & 30,7 & 1,58 & 2,53 \\
\hline 1 размольная & 23,5 & 13,8 & 58,4 & 0,65 & 15,28 \\
\hline 2 размольная & 10,5 & 13,8 & 55,5 & 0,69 & 7,25 \\
\hline 3 размольная & 6,0 & 13,6 & 48,3 & 0,79 & 4,74 \\
\hline 4 размольная & 5,1 & 13,6 & 47,9 & 0,82 & 4,18 \\
\hline 5 размольная & 8,2 & 13,4 & 49,6 & 0,92 & 7,54 \\
\hline 6 размольная & 1,3 & 13,0 & $-4,2$ & 2,35 & 3,06 \\
\hline 7 размольная & 7,0 & 13,8 & $-14,5$ & 2,03 & 14,21 \\
\hline$\sum$ Муки & 77,2 & & & $\mathrm{Zcp}=0,94$ & 72,49 \\
\hline Отруби 1 & 14,6 & 14,0 & - & 5,19 & 75,77 \\
\hline Отруби 2 & 8,2 & 13,2 & - & 4,96 & 40,67 \\
\hline$\sum$ Отрубей & 22,8 & 13,7 & - & $\mathrm{Zcp}=5,11$ & 116,45 \\
\hline Всего: & 100 & & & \multicolumn{2}{|c|}{ Ср. взвеш. = 1,89 \% } \\
\hline
\end{tabular}

Таблица 3

Выход, белизна и зольность продуктов размола зерна сорта Ацтек

\begin{tabular}{|c|c|c|c|c|c|}
\hline $\begin{array}{c}\text { Выход муки } \\
\text { и отрубей по системам }\end{array}$ & Выход, \% & Влажность, \% & $\begin{array}{l}\text { Белизна, } \\
\text { ед. пр. }\end{array}$ & Зольность, \% & $\begin{array}{c}\text { Выход× } \\
\text { зольность }\end{array}$ \\
\hline I дранная & 7,3 & 15,8 & 51,8 & 0,84 & 6,13 \\
\hline II дранная & 3,8 & 15,6 & 54,7 & 0,79 & 3,00 \\
\hline III дранная & 4,1 & 15,0 & 51,2 & 0,83 & 3,40 \\
\hline IV дранная & 1,9 & 15,0 & 42,5 & 1,12 & 2,13 \\
\hline 1 размольная & 23,0 & 15,2 & 64,5 & 0,54 & 12,42 \\
\hline 2 размольная & 9,2 & 15,2 & 59,7 & 0,53 & 4,88 \\
\hline 3 размольная & 5,4 & 14,8 & 55,9 & 0,59 & 3,19 \\
\hline 4 размольная & 4,1 & 14,8 & 56,3 & 0,57 & 2,34 \\
\hline 5 размольная & 9,6 & 14,6 & 61,8 & 0,60 & 5,76 \\
\hline 6 размольная & 1,6 & 13,6 & 12,7 & 2,03 & 3,25 \\
\hline 7 размольная & 6,4 & 13,6 & 8,9 & 1,23 & 7,87 \\
\hline$\sum$ Муки & 76,4 & & & $\mathrm{Zcp}=0,71$ & 54,36 \\
\hline Отруби 1 & 18,5 & 15,0 & - & 6,75 & 124,88 \\
\hline Отруби 2 & 5,1 & 13,2 & - & 4,71 & 24,02 \\
\hline$\sum$ Отрубей & 23,6 & & - & $\mathrm{Zcp}=6,31$ & 148,90 \\
\hline Всего: & 100 & & & \multicolumn{2}{|c|}{ Ср. взвеш. = 2,03\% } \\
\hline
\end{tabular}


Таблица 4

Выход, белизна и зольность продуктов размола зерна сорт Корнет

\begin{tabular}{|c|c|c|c|c|c|}
\hline $\begin{array}{l}\text { Выход муки и отру- } \\
\text { бей по системам }\end{array}$ & Выход, \% & Влажность, \% & $\begin{array}{c}\text { Белизна, } \\
\text { ед. пр. }\end{array}$ & Зольность, \% & $\begin{array}{c}\text { Выход× } \\
\text { зольность }\end{array}$ \\
\hline I дранная & 7,1 & 14,0 & 42,5 & 0,93 & 6,60 \\
\hline II дранная & 4,5 & 14,2 & 50,6 & 0,84 & 3,78 \\
\hline III дранная & 5,5 & 13,6 & 48,8 & 0,93 & 5,12 \\
\hline IV дранная & 2,6 & 12,8 & 38,0 & 1,28 & 3,33 \\
\hline 1 размольная & 15,7 & 13,6 & 57,9 & 0,58 & 9,11 \\
\hline 2 размольная & 10,3 & 13,6 & 55,3 & 0,56 & 5,77 \\
\hline 3 размольная & 5,8 & 13,0 & 49,6 & 0,54 & 3,13 \\
\hline 4 размольная & 4,5 & 13,0 & 48,9 & 0,67 & 3,02 \\
\hline 5 размольная & 7,4 & 13,0 & 56,4 & 0,78 & 5,77 \\
\hline 6 размольная & 4,2 & 12,6 & 49,9 & 0,84 & 3,53 \\
\hline 7 размольная & 0,9 & 12,6 & $-3,7$ & 2,01 & 1,81 \\
\hline 8 размольная & 7,1 & 12,4 & $-11,2$ & 1,54 & 10,93 \\
\hline$\sum$ Муки & 75,6 & & & $\mathrm{Zcp}=0,82$ & 61,89 \\
\hline Отруби 1 & 14,8 & 12,8 & - & 5,05 & 74,74 \\
\hline Отруби 2 & 9,6 & 11,8 & - & 4,51 & 43,30 \\
\hline$\sum$ Отрубей & 24,4 & & - & \multicolumn{2}{|c|}{$\mathrm{Zcp}=4,84$} \\
\hline & & & & \multicolumn{2}{|c|}{118,04} \\
\hline Всего: & 100 & & & \multicolumn{2}{|l|}{ Ср. взвеш.= 1,80 \% } \\
\hline
\end{tabular}

Таблица 5

Выход, белизна и зольность продуктов размола зерна сорта Топаз

\begin{tabular}{|c|c|c|c|c|c|}
\hline $\begin{array}{c}\text { Выход муки } \\
\text { и отрубей по системам }\end{array}$ & Выход, \% & Влажность, \% & $\begin{array}{c}\text { Белиз- } \\
\text { на, ед. пр. }\end{array}$ & Зольность, \% & $\begin{array}{c}\text { Выход× } \\
\text { зольность }\end{array}$ \\
\hline I дранная & 6,7 & 15,4 & 52,2 & 0,79 & 5,29 \\
\hline II дранная & 5,7 & 15,6 & 60,7 & 0,62 & 6,32 \\
\hline III дранная & 7,0 & 15,6 & 59,6 & 0,64 & 4,48 \\
\hline IV дранная & 2,3 & 15,0 & 41,8 & 1,09 & 2,51 \\
\hline 1 размольная & 15,8 & 15,4 & 68,3 & 0,53 & 8,37 \\
\hline 2 размольная & 10,4 & 14,8 & 61,4 & 0,57 & 5,93 \\
\hline 3 размольная & 6,7 & 15,0 & 59,2 & 0,58 & 3,89 \\
\hline 4 размольная & 4,4 & 14,8 & 57,6 & 0,61 & 2,68 \\
\hline 5 размольная & 3,4 & 14,6 & 57,3 & 0,70 & 2,38 \\
\hline 6 размольная & 1,7 & 14,6 & 14,8 & 2,17 & 3,69 \\
\hline 7 размольная & 9,1 & 14,6 & 8,1 & 1,19 & 10,83 \\
\hline$\sum$ Муки & 73,2 & & & $\mathrm{Zcp}=0,77$ & 56,37 \\
\hline Отруби 1 & 18,4 & 15,4 & - & 5,67 & 104,33 \\
\hline Отруби 2 & 8,4 & 14,2 & - & 4,35 & 36,54 \\
\hline$\sum$ Отрубей & 26,8 & & - & $\mathrm{Zcp}=5,26$ & 140,87 \\
\hline Всего: & 100 & & & Ср. взвеш. = 1,97 \% & \\
\hline
\end{tabular}


На втором этапе исследований построили кумулятивные кривые тритикалевой муки исследуемых образцов зерна тритикале. В Таблице 6 представлены данные, в т.ч. зольность каждого потока муки, его выход, выход муки по нарастающей, зольность умноженное на выход муки и средневзвешенную зольность, для построения кумулятивной кривой зольности тритикалевой муки из сорта тритикале Консул. Ранжирование данных представлено по нарастающему значению зольности.

На Рисунке 1 представлена кумулятивная кривая зольности тритикалевой муки сорта Консул.
Из Рисунка 1 видно, что кумулятивную кривую зольности тритикалевой муки сорта Консул можно разбить на три линейных участка, каждый из которых имеет соответствующий физический смысл. Первый участок - измельчение центральной части эндосперма зерна тритикале и включает в себя муку из 1-3 размольных систем и муку из II драной системы. Выход тритикалевой муки на этом участке составил $42,2 \%$, а зольность муки - 0,63 \%.

Далее следует второй линейный участок кумулятивной кривой, на котором происходит измельчение эндосперма и периферийной части,

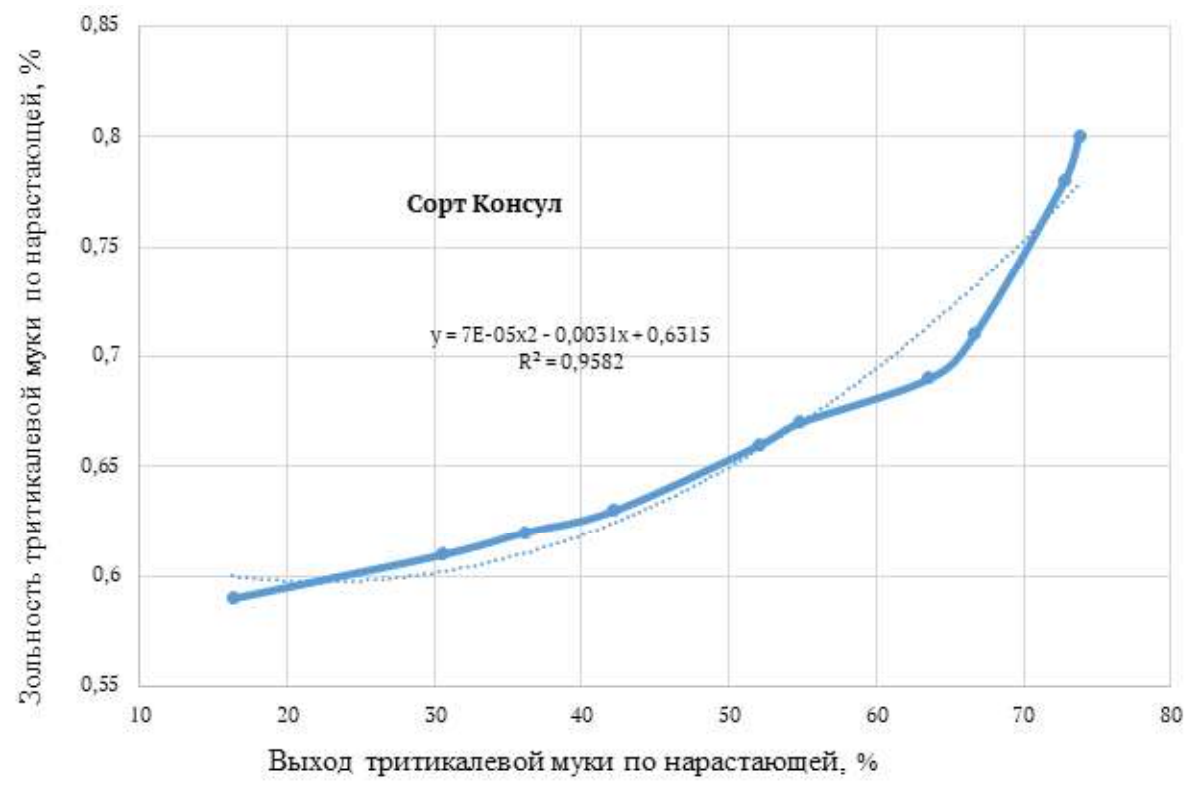

Рисунок 1. Кумулятивная кривая зольности тритикалевой муки сорта Консул

Таблица 6

Зависимость зольности тритикалевой муки от выхода сорта Консул

\begin{tabular}{|c|c|c|c|c|c|c|}
\hline $\begin{array}{l}\text { Технологиче- } \\
\text { ская система }\end{array}$ & $\begin{array}{c}\text { Зольность } \\
\text { муки, \% }\end{array}$ & $\begin{array}{c}\text { Выход } \\
\text { муки, \% }\end{array}$ & $\begin{array}{c}\text { Суммар- } \\
\text { ный выход } \\
\text { муки, \% } \\
\end{array}$ & $\begin{array}{c}\text { Выходх } \\
\text { Зольность }\end{array}$ & $\begin{array}{c}\text { Выход× } \\
\text { Зольность }\end{array}$ & $\begin{array}{r}\text { Средне-взе- } \\
\text { шенная золь- } \\
\text { ность муки, \% } \\
\end{array}$ \\
\hline 1 размольная & 0,59 & 16,3 & 16,3 & 9,617 & 9,617 & 0,59 \\
\hline 2 размольная & 0,63 & 14,3 & 30,6 & 9,009 & 18,626 & 0,61 \\
\hline 3 размольная & 0,67 & 5,5 & 36,1 & 3,685 & 22,311 & 0,62 \\
\hline II дранная & 0,68 & 6,1 & 42,2 & 4,148 & 26,495 & 0,63 \\
\hline $\begin{array}{l}3 \text { размольная система + } \\
\text { III драная }\end{array}$ & 0,79 & 9,9 & 52,1 & 7,821 & 34,316 & 0,66 \\
\hline 4 размольная & 0,82 & 2,7 & 54,8 & 2,214 & 36,530 & 0,67 \\
\hline I дранная & 0,83 & 8,8 & 63,6 & 7,304 & 43,834 & 0,69 \\
\hline IV дранная & 1,10 & 3,1 & 66,7 & 3,41 & 47,244 & 0,71 \\
\hline 5 размольная & 1,55 & 6,1 & 72,8 & 9,455 & 56,699 & 0,78 \\
\hline 6 размольная & 2,12 & 1,0 & 73,8 & 2,12 & 58,819 & 0,80 \\
\hline
\end{tabular}


включающий в себя потоки муки из 3-4 размольных систем и муку из I и III драных систем. Выход тритикалевой муки на этом участке составил $24,5 \%$, а зольность муки - 0,85 \%.

И на третьем, заключительном участке кумулятивной кривой происходит вымол тритикалевых оболочек и включает в себя потоки муки из I драной системы и 5-6 размольных систем. Выход тритикалевой муки на этом участке составил 7,1\%, а зольность муки - 1,65 \%.

Общий выход тритикалевой муки из сорта Консул составил 73,8 \% зольностью 0,80 \%. Величина достоверности аппроксимации графика составила 0,96 и показывает высокую достоверность зависимости зольности тритикалевой муки от ее выхода.

Таким образом, можно на мукомольных заводах можно будет выделять три основных потока муки, из которых, в свою очередь, можно формировать различные сорта муки, предназначенные для хлебопекарных, кондитерских, макаронных и пищеконцентратных предприятий.

В Таблице 7 представлены данные для построения кумулятивной кривой зольности тритикалевой муки из сорта тритикале Капрал. Ранжирование данных представлено по нарастающему значению зольности тритикалевой муки.

На Рисунке 2 представлена кумулятивная кривая зольности тритикалевой муки сорта Капрал.
Из Рисунка 2 видно, что кумулятивную кривую зольности тритикалевой муки сорта Капрал можно разбить на три линейных участка, каждый из которых имеет соответствующий физический смысл. Первый участок - измельчение центральной части эндосперма зерна тритикале и включает в себя муку из 1 и 2 размольных систем. Выход тритикалевой муки на этом участке составил 34,0 \%, а 30льность муки - 0,66 \%.

Далее следует второй линейный участок кумулятивной кривой, на котором происходит измельчение эндосперма и периферийной части, включающий в себя потоки муки из 3-5 размольных систем и муку из I-III драных систем. Выход тритикалевой муки на этом участке составил 43,3 \%, а зольность муки - 0,91\%.

И на третьем, заключительном участке кумулятивной кривой происходит вымол тритикалевых оболочек и включает в себя потоки муки из IV драной системы и 5-6 размольных систем. Выход тритикалевой муки на этом участке составил 9,9\%, а зольность муки - 2,00\%.

Общий выход тритикалевой муки из сорта Капрал составил 77,2 \% зольностью $0,94 \%$. Величина достоверности аппроксимации графика составила 0,96 и показывает высокую достоверность зависимости зольности тритикалевой муки от ее выхода.

В Таблице 8 представлены данные для построения кумулятивной кривой зольности тритикалевой

Таблица 7

Зависимость зольности тритикалевой муки от выхода сорта Капрал

\begin{tabular}{|c|c|c|c|c|c|c|}
\hline $\begin{array}{l}\text { Технологиче- } \\
\text { ская система }\end{array}$ & $\begin{array}{c}\text { Зольность } \\
\text { муки, \% }\end{array}$ & $\begin{array}{c}\text { Выход } \\
\text { муки, \% }\end{array}$ & $\begin{array}{c}\text { Суммар- } \\
\text { ный выход } \\
\text { муки, \% }\end{array}$ & $\begin{array}{c}\text { Выход× } \\
\text { Зольность }\end{array}$ & $\begin{array}{l}\Sigma \text { Выход× } \\
\text { Зольность }\end{array}$ & $\begin{array}{l}\text { Средне-взешенная } \\
\text { зольность муки, \% }\end{array}$ \\
\hline 1 размольная & 0,65 & 23,5 & 23,5 & 15,275 & 15,275 & 0,65 \\
\hline 2 размольная & 0,69 & 10,5 & 34,0 & 7,245 & 22,52 & 0,66 \\
\hline 3 размольная & 0,79 & 6,0 & 40,0 & 4,74 & 27,26 & 0,68 \\
\hline 4 размольная & 0,82 & 5,1 & 45,1 & 4,182 & 31,442 & 0,70 \\
\hline 5 размольная & 0,92 & 8,2 & 53,3 & 7,544 & 38,986 & 0,73 \\
\hline I дранная & 0,96 & 4,8 & 58,1 & 4,608 & 43,594 & 0,75 \\
\hline II дранная & 0,97 & 3,2 & 61,3 & 3,104 & 46,698 & 0,76 \\
\hline III дранная & 1,0 & 6,0 & 67,3 & 6 & 52,698 & 0,78 \\
\hline IV дранная & 1,58 & 1,6 & 68,9 & 2,528 & 55,226 & 0,80 \\
\hline 7 размольная & 2,03 & 7,0 & 75,9 & 14,21 & 69,436 & 0,91 \\
\hline 6 размольная & 2,35 & 1,3 & 77,2 & 3,055 & 72,486 & 0,94 \\
\hline
\end{tabular}




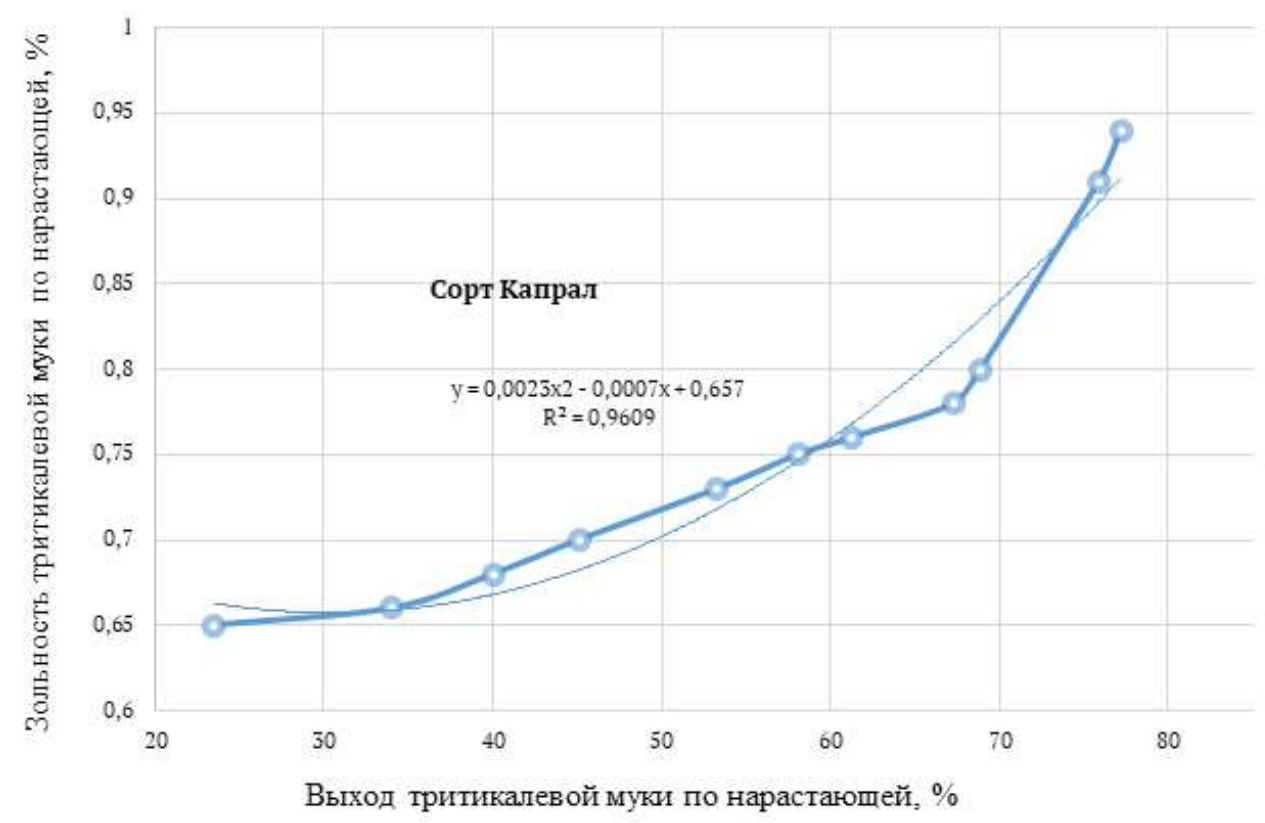

Рисунок 2. Кумулятивная кривая зольности тритикалевой муки сорта Капрал

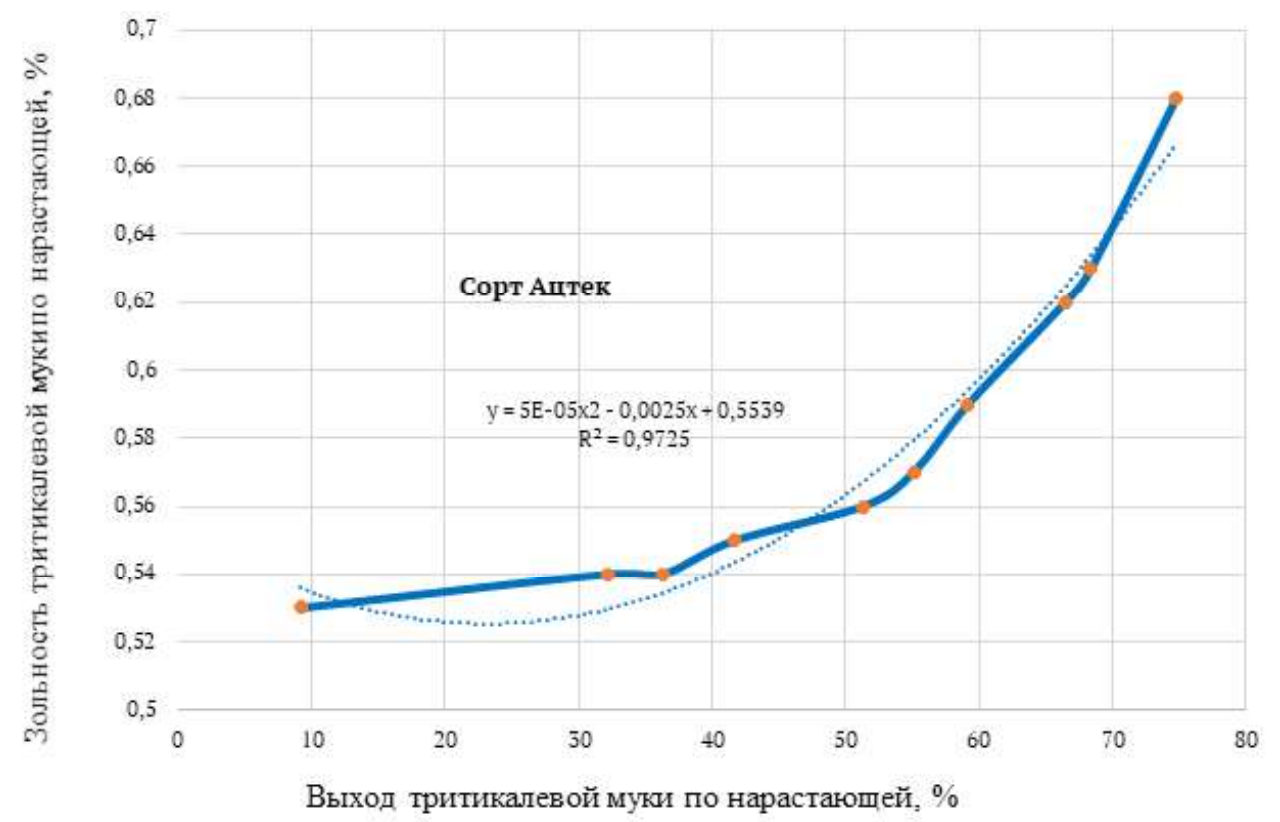

Рисунок 3. Кумулятивная кривая зольности тритикалевой муки сорта Ацтек

муки из сорта тритикале Ацтек. Ранжирование данных представлено по нарастающему значению зольности тритикалевой муки.

На Рисунке 3 представлена кумулятивная кривая зольности тритикалевой муки сорта Ацтек.

Из Рисунка 3 видно, что кумулятивную кривую зольности тритикалевой муки сорта Ацтек можно разбить на три линейных участка, каждый из которых имеет соответствующий физический смысл. Первый участок - измельчение центральной ча- сти эндосперма зерна тритикале и включает в себя муку из 1, 2 и 4 размольных систем. Выход тритикалевой муки на этом участке составил 36,3 \%, а зольность муки - 0,54 \%.

Далее следует второй линейный участок кумулятивной кривой, на котором происходит измельчение эндосперма и периферийной части, включающий в себя потоки муки из 3, 5 размольных систем и муку из II и III драных систем. Выход тритикалевой муки на этом участке составил $22,9 \%$, а зольность муки - 0,67 \%. 
Таблица 8

Зависимость зольности тритикалевой муки от выхода сорта Ацтек

\begin{tabular}{|c|c|c|c|c|c|c|}
\hline $\begin{array}{l}\text { Технологиче- } \\
\text { ская система }\end{array}$ & $\begin{array}{c}\text { Зольность } \\
\text { муки, \% }\end{array}$ & $\begin{array}{c}\text { Выход } \\
\text { муки, \% }\end{array}$ & $\begin{array}{c}\text { Суммар- } \\
\text { ный выход } \\
\text { муки, \% }\end{array}$ & $\begin{array}{c}\text { Выходх } \\
\text { Зольность }\end{array}$ & $\begin{array}{c}\Sigma \text { Выходх } \\
\text { Зольность }\end{array}$ & $\begin{array}{c}\text { Средне-взе- } \\
\text { шенная золь- } \\
\text { ность муки, \% }\end{array}$ \\
\hline 2 размольная & 0,53 & 9,2 & 9,2 & 4,876 & 4,876 & 0,53 \\
\hline 1 размольная & 0,54 & 23,0 & 32,2 & 12,42 & 17,276 & 0,54 \\
\hline 4 размольная & 0,57 & 4,1 & 36,3 & 2,337 & 19,633 & 0,54 \\
\hline 3 размольная & 0,59 & 5,4 & 41,7 & 3,186 & 22,819 & 0,55 \\
\hline 5 размольная & 0,60 & 9,6 & 51,3 & 5,76 & 28,579 & 0,56 \\
\hline II дранная & 0,79 & 3,8 & 55,1 & 3,002 & 31,581 & 0,57 \\
\hline III дранная & 0,83 & 4,1 & 59,2 & 3,403 & 34,984 & 0,59 \\
\hline I дранная & 0,84 & 7,3 & 66,5 & 6,132 & 41,116 & 0,62 \\
\hline IV дранная & 1,12 & 1,9 & 68,4 & 2,128 & 43,244 & 0,63 \\
\hline 7 размольная & 1,23 & 6,4 & 74,8 & 7,872 & 51,116 & 0,68 \\
\hline 6 размольная & 2,03 & 1,6 & 76,4 & 3,248 & 54,364 & 0,71 \\
\hline
\end{tabular}

Таблица 9

Зависимость зольности тритикалевой муки от выхода сорта Корнет

\begin{tabular}{|c|c|c|c|c|c|c|}
\hline $\begin{array}{l}\text { Технологиче- } \\
\text { ская система }\end{array}$ & $\begin{array}{c}\text { Зольность } \\
\text { муки, \% }\end{array}$ & $\begin{array}{c}\text { Выход } \\
\text { муки, \% }\end{array}$ & $\begin{array}{c}\text { Суммар- } \\
\text { ный выход } \\
\text { муки, \% }\end{array}$ & $\begin{array}{c}\text { Выход× } \\
\text { Зольность }\end{array}$ & $\begin{array}{c}\Sigma \text { Выходх } \\
\text { Зольность }\end{array}$ & $\begin{array}{c}\text { Средне-взе- } \\
\text { шенная золь- } \\
\text { ность муки, \% }\end{array}$ \\
\hline 3 размольная & 0,54 & 5,8 & 5,8 & 3,132 & 3,132 & 0,54 \\
\hline 2 размольная & 0,56 & 10,3 & 16,1 & 5,768 & 8,900 & 0,55 \\
\hline 1 размольная & 0,58 & 15,7 & 31,8 & 9,106 & 18,006 & 0,57 \\
\hline 4 размольная & 0,67 & 4,5 & 36,3 & 3,015 & 21,021 & 0,58 \\
\hline 5 размольная & 0,78 & 7,4 & 43,7 & 5,772 & 26,793 & 0,61 \\
\hline 6 размольная & 0,84 & 4,2 & 47,9 & 3,528 & 30,321 & 0,63 \\
\hline II дранная & 0,84 & 4,5 & 52,4 & 3,78 & 34,101 & 0,65 \\
\hline I дранная & 0,93 & 7,1 & 59,5 & 6,603 & 40,704 & 0,68 \\
\hline III дранная & 0,93 & 5,5 & 65,0 & 5,115 & 45,819 & 0,70 \\
\hline IV дранная & 1,28 & 2,6 & 67,6 & 3,328 & 49,147 & 0,73 \\
\hline 8 размольная & 1,54 & 7,1 & 74,7 & 10,934 & 60,081 & 0,80 \\
\hline 7 размольная & 2,01 & 0,9 & 75,6 & 1,809 & 61,89 & 0,82 \\
\hline
\end{tabular}

И на третьем, заключительном участке кумулятивной кривой происходит вымол тритикалевых оболочек и включает в себя потоки муки из I и IV драных систем и 5-6 размольных систем. Выход тритикалевой муки на этом участке составил $17,2 \%$, а зольность муки - 1,13 \%.

Общий выход тритикалевой муки из сорта Ацтек составил 76,4 \% зольностью 0,71 \%. Величина до- стоверности аппроксимации графика составила 0,97 и показывает высокую достоверность зависимости зольности тритикалевой муки от ее выхода.

В Таблице 9 представлены данные для построения кумулятивной кривой зольности тритикалевой муки из сорта тритикале Корнет. Ранжирование данных представлено по нарастающему значению зольности тритикалевой муки. 
На Рисунке 4 представлена кумулятивная кривая зольности тритикалевой муки сорта Консул.

Из Рисунка 4 видно, что кумулятивную кривую зольности тритикалевой муки сорта Корнет можно разбить на три линейных участка, каждый из которых имеет соответствующий физический смысл. Первый участок - измельчение центральной части эндосперма зерна тритикале и включает в себя муку из 3, 2 и 1 размольных систем и муку из II и I драных систем. Выход тритикалевой муки на этом участке составил 31,8 \%, а зольность муки - 0,57 \%.

Далее следует второй линейный участок кумулятивной кривой, на котором происходит измельчение эндосперма и периферийной части, включающий в себя потоки муки из 4-6 размольных систем и муку из II и I драных систем. Выход тритикалевой муки на этом участке составил $27,7 \%$, а зольность муки - 0,82 \%.

И на третьем, заключительном участке кумулятивной кривой происходит вымол тритикалевых оболочек и включает в себя потоки муки из III и IV драных систем и 6-7 размольных систем. Выход тритикалевой муки на этом участке составил $16,1 \%$, а зольность муки $-1,32 \%$.

Общий выход тритикалевой муки из сорта Корнет составил 75,6 \% зольностью $0,82 \%$. Величина достоверности аппроксимации графика составила 0,99 и показывает высокую достоверность зависимости зольности тритикалевой муки от ее выхода.
В Таблице 10 представлены данные для построения кумулятивной кривой зольности тритикалевой муки из сорта тритикале Топаз. Ранжирование данных представлено по нарастающему значению зольности тритикалевой муки.

На Рисунке 5 представлена кумулятивная кривая зольности тритикалевой муки сорта Топаз.

Из Рисунка 5 видно, что кумулятивную кривую зольности тритикалевой муки сорта Топаз можно разбить на три линейных участка, каждый из которых имеет соответствующий физический смысл. Первый участок - измельчение центральной части эндосперма зерна тритикале и включает в себя муку из 1-4 размольных систем. Выход тритикалевой муки на этом участке составил 37,3 \%, а зольность муки - 0,56 \%.

Далее следует второй линейный участок кумулятивной кривой, на котором происходит измельчение эндосперма и периферийной части, включающий в себя потоки тритикалевой муки из II, III и I драных систем и поток муки из 5 размольной системы. Выход тритикалевой муки на этом участке составил $22,8 \%$, а зольность муки $0,69 \%$.

И на третьем, заключительном участке кумулятивной кривой происходит вымол тритикалевых оболочек и включает в себя потоки муки из IV драной системы и 5-6 размольных систем. Выход тритикалевой муки на этом участке составил $13,1 \%$, а зольность муки - 1,30 \%.

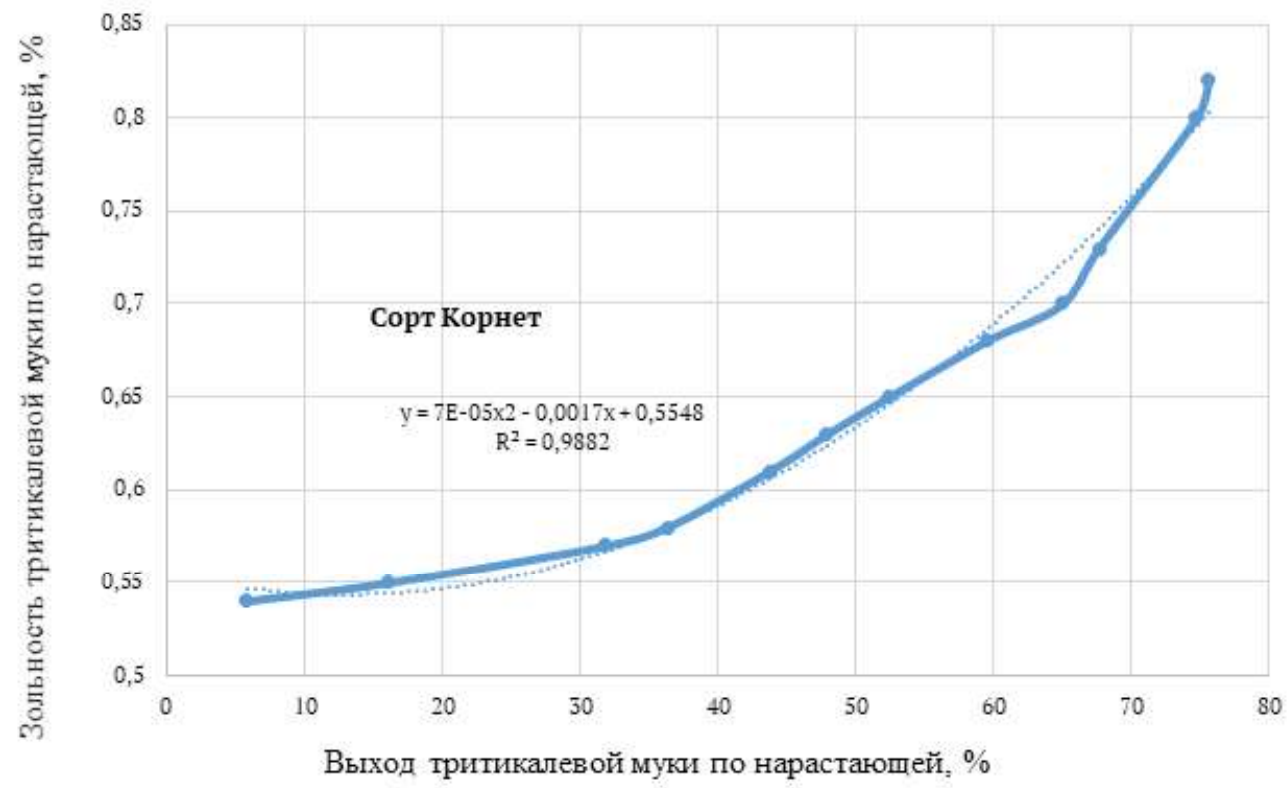

Рисунок 4. Кумулятивная кривая зольности тритикалевой муки сорта Корнет 
Таблица 10

Зависимость зольности тритикалевой муки от выхода из сорта Топаз

\begin{tabular}{lcccccc}
\hline $\begin{array}{c}\text { Технологиче- } \\
\text { ская система }\end{array}$ & $\begin{array}{c}\text { Зольность } \\
\text { муки, \% }\end{array}$ & $\begin{array}{c}\text { Выход } \\
\text { муки, \% }\end{array}$ & $\begin{array}{c}\text { Суммарный } \\
\text { выход муки, }\end{array}$ & $\begin{array}{c}\text { Выходх } \\
\text { Зольность }\end{array}$ & $\begin{array}{c}\text { г Выходх } \\
\text { Зольность }\end{array}$ & $\begin{array}{c}\text { Средне-взешенная } \\
\text { зольность муки, \% }\end{array}$ \\
\hline 1 размольная & 0,53 & 15,8 & 15,8 & 8,374 & 8,374 & 0,53 \\
2 размольная & 0,57 & 10,4 & 26,2 & 5,928 & 14,301 & 0,55 \\
3 размольная & 0,58 & 6,7 & 32,9 & 3,886 & 18,187 & 0,55 \\
4 размольная & 0,61 & 4,4 & 37,3 & 2,684 & 20,871 & 0,56 \\
II дранная & 0,62 & 5,7 & 43,0 & 3,534 & 24,405 & 0,57 \\
III дранная & 0,64 & 7,0 & 50,0 & 4,48 & 28,885 & 0,58 \\
5 размольная & 0,70 & 3,4 & 53,4 & 2,38 & 31,265 & 0,59 \\
I дранная & 0,79 & 6,7 & 60,1 & 5,293 & 36,558 & 0,61 \\
IV дранная & 1,09 & 2,3 & 62,4 & 2,507 & 39,065 & 0,63 \\
7 размольная & 1,19 & 9,1 & 71,5 & 10,829 & 49,894 & 0,70 \\
6 размольная & 2,17 & 1,7 & 73,2 & 3,689 & 53,583 & 0,73 \\
\hline
\end{tabular}

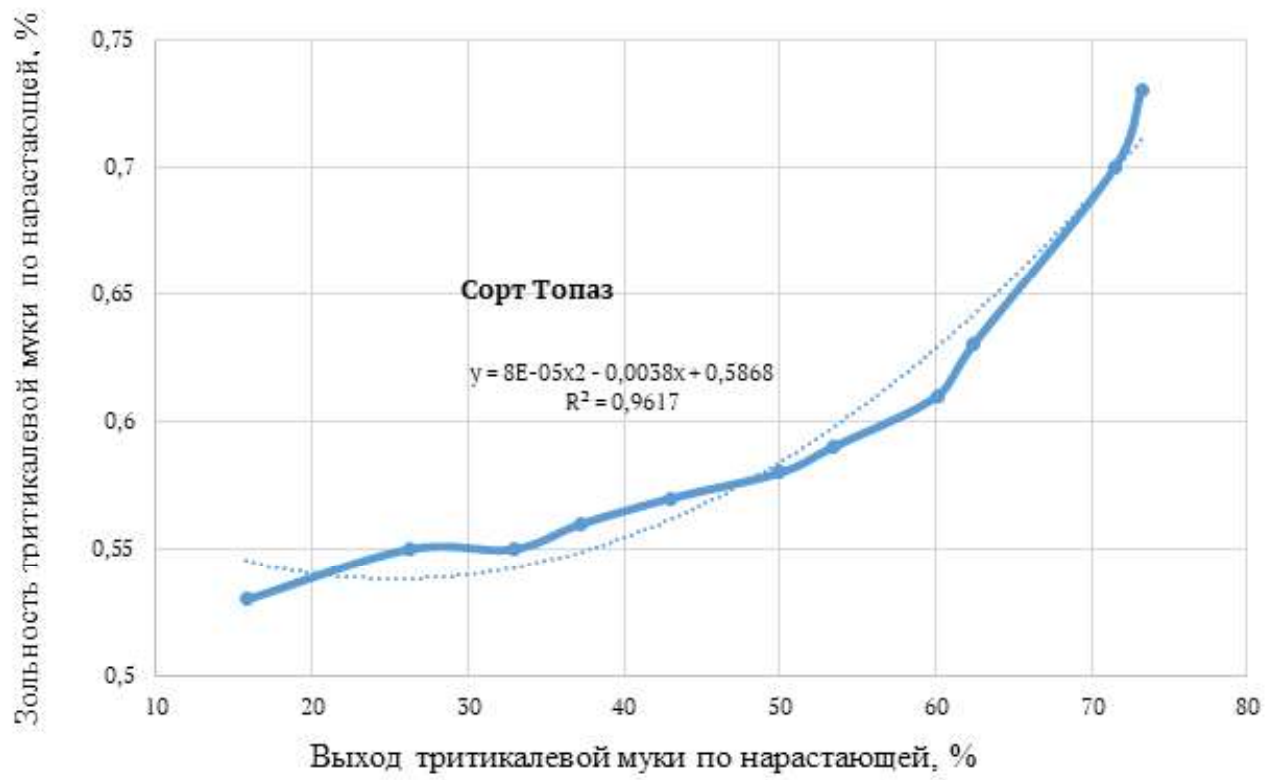

Рисунок 5. Кумулятивная кривая зольности тритикале сорта Топаз

Общий выход тритикалевой муки из сорта Топаз составил 73,2 \% зольностью 0,73 \%. Величина достоверности аппроксимации графика составила 0,96 и показывает высокую достоверность зависимости зольности тритикалевой муки от ее выхода.

\section{Выводы}

Таким образом, по результатам проведенных исследований, установлено наличие 3-х этапов формирования тритикалевой муки при переработке новых сортов зерна тритикале, что достаточно четко видно из графиков кумулятивных кривых.
Первый участок - измельчение центральной части эндосперма и включает в себя муку, полученную на 3-4-х размольных и одной драной технологических системах. Далее идет второй участок, на котором происходит измельчение эндосперма и периферийной части, включающий в себя 3-4 потока. На третьем, заключительном участке происходит вымол оболочек и включает в себя 3-4 потока. Общий выход тритикалевой муки из сорта Консул составил 73,8 \% зольностью $0,80 \%$, из сорта Капрал составил 77,2 \% зольностью 0,94 \%, из сорта Ацтек составил 76,4 \% зольностью 0,71\%, из сорта Корнет составил 75,6 \% зольностью $0,82 \%$, из сорта Топаз составил 73,2 \% зольностью 0,73 \%. 
Наилучшими мукомольными свойствами из представленных образцов тритикале обладает сорт Ацтек выход тритикалевой муки высшего сорта Т-60 из которого составил 59,2\% с зольностью $0,59 \%$. Наихудшими мукомольными свойствами обладает сорт тритикале Капрал из которого не удалось получить ни одного процента тритикалевой муки высшего сорта Т-60. Установлено высокая достоверность зависимости зольности тритикалевой муки от ее выхода, которая составила 0,96-0,99.

\section{Литература}

Андреев, Н. Р., Носовская, Л. П., Адикаева, Л. В., Некрасова, О. А., \& Гольдштейн, В. Г. (2016). Качество сухого корма из вторичных продуктов переработки зерна тритикале на крахмал. Достижения науки и техники АПК, 30(11), 73-75.

Витол, И. С., Мелешкина, Е. П., Кандроков, Р. Х., Вережникова, И. А., \& Карпиленко, Г. П. (2017). Особенности биохимического состава тритикалевой муки разных сортов. Хранение и переработка зерна, 2, 30-32.

Витол, И. С., Мелешкина, Е. П., Кандроков, Р. Х., Вережникова, И. А., \& Карпиленко, Г. П. (2016). Биохимическая характеристика новых сортов тритикалевой муки. Хлебопродукты, 2, 42-43.

Витол, И. С., Мелешкина, Е. П., \& Кандроков, Р. Х. (2016). Продукты переработки зерна тритикале как объект для ферментативной модификации. Хранение и переработка сельхозсырья, 9, 14-16.

Кандроков, Р. Х., Стариченков, А. А., \& Штейнберг, Т. С. (2015). Влияние ГТО на выход и качество тритикалевой муки. Хлебопродукты, 1 , 64-65.

Кандроков, Р. Х., \& Панкратов, Г. Н. (2017). Технология переработки зерна тритикале в крупу типа «манная». Хлебопродукты, 1, 52-53.

Карчевская, О. В., Дремучева, Г. Ф., \& Грабовец, А. И. (2013). Научные основы и технологические аспекты применения зерна тритикале в производстве хлебобулочных изделий. Хлебопечение России, 5, 28-29.

Магомедов, Г. О., Малютина, Т. Н., \& Шапкарина, А. И. (2016). Разработка технологии сбивных мучных кондитерских изделий повышенной пищевой ценности с применением тритикалевой муки. Вестник ВГУИТ, 1, 106-109. https://doi.org/10.20914/2310-1202-2016-1-106109

Мелешкина, Е. П., Панкратов, Г. Н., Панкратьева, И. А., Чиркова, Л. В., Кандроков, Р. Х., Витол, И. С., Игорянова, Н. А., Политуха, О. В., \&
Туляков, Д. Г. (2018). Тритикале (технологии переработки): Монография. М.: Изд-во ФЛИНТА.

Панкратов, Г. Н., Мелешкина, Е. П., Кандроков, Р. Х., \& Витол, И. С. (2016). Технологические свойства новых сортов тритикалевой муки. Хлебопродукты, 1, 60-62.

Панкратов, Г. Н., Кандроков, Р. Х., \& Щербакова, Е. В. (2016). Процесс измельчения зерна тритикале. Хлебопродукты, 10, 59-61.

Сокол, Н. В. (2014). Тритикале - хлебная культура. Германия: Palmarium Academic Pulishing.

Blum, A. (2014). The abiotic stress response and adaptation of triticale - A review. Cereal Research Communications, 42(3), 359-375. https://doi. org/10.1556/CRC.42.2014.3.1

Bona, L., Acs, E., Lantos, C., Purnhauser, L., Lango, B., \& Tomoskozi, S. (2013). Human utilization of triticale: Technological and features, milling and baking experiments. In: Abstracts 8th international triticale symposium (p. 46). Ghent, Belgium.

Dennett, A. L., Cooper, K. V., \& Trethowan, R. M. (2013). The genotypic and phenotypic interaction of wheat and rye storage proteins in primary triticale. Euphytica, 194, 235-242. https://doi. org/10.1007/s10681-013-0950-y

Dennett, A. L., \& Trethowan, R. M. (2013). The influence of dual-purpose production on triticale grain quality. Cereal Research Communications, 41(3), 448-457. https://doi.org/10.1556/ CRC.2013.0022

De Laethauwer, S., Reheul, D., De Riek, J., \& Haesaert, G. (2012). Vp1 expression profiles during kernel development in six genotypes of wheat, triticale and rye. Euphytica, 188, 61-70. https://doi. org/10.1007/s10681-011-0613-9

He, M. L., McAllister, T. A., Hernandez-Calva, L. M., Aalhus, J. L., Dugan, M. E. R, \& McKinnon, J. J. (2014). Effect of dietary inclusion of triticale dried distillers' grain and oilseeds on quality and fatty acid profile of meat from feedlot steers. Meat Science, 97(1), 76-82. https://doi.org/10.1016/j. meatsci.2014.01.008

Kandrokov, R., Pankratov, G., Meleshkina, E., Vitol, I., \& Tulyakov D. (2019). Effective technological scheme for processing triticale grain into high-quality baker's grade flour. Foods and Raw Materials, 7(1), 107-117. https://doi. org/10.21603/2308-4057-2019-1-107-117

Meleshkina, E. P., Pankratov, G. N., Vitol, I. S., Kandrokov, R. H., \& Tulyakov, D. G. (2017). Innovative trends in the development of advanced Triticale grain processing technology. Foods and Raw Materials, 5(2), 70-82. https://doi. org/10.21603/2308-4057-2017-2-70-82 


\title{
Milling properties of new grades of triticale grain
}

\author{
Roman Kh. Kandrokov \\ FSBEI HE "Moscow State University of Food Production" \\ 11, Volokolamskoe highway, Moscow, 125080, Russian Federation \\ E-mail:nart132007@mail.ru
}

Georgy N. Pankratov

VNIIZ - branch of the Federal State Budgetary Scientific Institution "Federal Scientific Center for Food Systems named after V.M. Gorbatov "RAS 11, st. Dmitrovskoe highway, Moscow, 127434, Russian Federation E-mail: pankratof.gn@yandex.ru

\author{
Alexander A. Ryndin \\ "Advanced food technology and food safety" \\ FSBEI HE "Moscow State University of Food Production" \\ 11, Volokolamskoe highway, Moscow, 125080, Russian Federation \\ E-mail: aleksandr-ryndin@rambler.ru
}

Pavel M. Konorev Russian State Agrarian University - Moscow Agricultural Academy named after K.A. Timiryazeva 49, st. Timiryazevskaya, Moscow, 127550, Russian Federation E-mail:konorev@rgau-msha.ru

\begin{abstract}
The use in various branches of the food and processing industry of processed products of an unconventional grain crop - triticale, is currently attracting more and more attention from both grain producers and scientists in our country and abroad. This circumstance is due to the increase in acreage, the creation of winter varieties of triticale grain, included in the register of varieties, numerous studies of the technological, biochemical and biological potential of triticale grain. In this regard, the purpose of our research was to determine the potential milling properties of new varieties of winter triticale grain as a raw material for the production of triticale flour for various purposes. The object of research on the potential milling properties of winter grain triticale is 5 new varieties - Consul, Kapral, Aztec, Cornet and Topaz. The determination of the potential milling properties of new varieties of triticale was carried out on laboratory mills PCA-4 with rifled and smooth, microrough rollers. All torn systems and the grinding system used grooved rollers with a grooved edge on the tip, and the grinding systems used rollers with a smooth micro-rough surface. The presence of 3 stages of the formation of triticale flour was established, which is clearly seen from the graphs of the cumulative curves. The first section is the grinding of the central part of the endosperm and includes 3-4 streams. Next comes the second section, where the endosperm and the peripheral part are ground, which includes 3-4 streams. In the third, final section, the shells are ground out and includes 3-4 streams. The total yield of triticale flour from the Consul variety was $73.8 \%$ with an ash content of $0.80 \%$, from the Kapral variety it was $77.2 \%$ with an ash content of $0.94 \%$, from the Aztec variety it was $76.4 \%$ with an ash content of $0.71 \%$, from the Cornet variety it was $75.6 \%$ ash content $0.82 \%$, from Topaz grade it was $73.2 \%$ ash content $0.73 \%$. The best milling properties of the presented samples of triticale are possessed by the Aztec variety, the yield of triticale flour of the highest grade T- 60 of which was $59.2 \%$ with an ash content of $0.59 \%$.
\end{abstract}

Keywords: winter triticale, milling properties, flour, yield, whiteness, ash content, cumulative curve

\section{References}

Andreev, N. R., Nosovskaya, L. P., Adikaeva, L. V., Nekrasova, O. A., \& Gol'dshtein, V. G. (2016). Kachestvo sukhogo korma iz vtorichnykh produktov pererabotki zerna tritikale na krakhmal [The quali- ty of dry feed from secondary products of processing grain triticale for starch]. Dostizheniya nauki i tekhniki APK [Achievements of Science and Technology of the Agro-Industrial Complex], 30(11), 73-75.

Kandrokov, R. Kh., \& Pankratov, G. N. (2017). Tekhnologiya pererabotki zerna tritikale $\mathrm{v}$ krupu 
tipa «mannaya» [Triticale grain processing technology in semolina type groats]. Khleboprodukty [Bakery Products], 1, 52-53.

Kandrokov, R. Kh., Starichenkov, A. A., \& Shteinberg, T. S. (2015). Vliyanie GTO na vykhod i kachestvo tritikalevoi muki [The influence of the TRP on the exit and quality of triticale flour]. Khleboprodukty [Bakery Products], 1, 64-65.

Karchevskaya, O. V., Dremucheva, G. F., \& Grabovets, A. I. (2013). Nauchnye osnovy i tekhnologicheskie aspekty primeneniya zerna tritikale $\mathrm{v}$ proizvodstve khlebobulochnykh izdelii [Scientific basis and technological aspects of the use of triticale grain in the production of bakery products]. Khlebopechenie Rossii [Russian Bakery], 5, 28-29.

Magomedov, G. O., Malyutina, T. N., \& Shapkarina, A. I. (2016). Razrabotka tekhnologii sbivnykh muchnykh konditerskikh izdelii povyshennoi pishchevoi tsennosti s primeneniem tritikalevoi muki [Technology development whipped flour confectionery products of increased nutritional value with the use of triticale flour]. Vestnik VGUIT [Voronezh State Technical University Bulletin], 1, 106-109. https://doi. org/10.20914/2310-1202-2016-1-106-109

Meleshkina, E. P., Pankratov, G. N., Pankrat'eva, I. A., Chirkova, L. V., Kandrokov, R. Kh., Vitol, I. S., Igoryanova, N. A., Politukha, O. V., \& Tulyakov, D. G. (2018). Tritikale (tekhnologii pererabotki): Monografiya [Triticale (processing technology): Monograph]. Moscow: Izd-vo FLINTA.

Pankratov, G. N., Kandrokov, R. Kh., \& Shcherbakova, E. V. (2016). Protsess izmel'cheniya zerna triticale [Grain grinding process triticale]. Khleboprodukty [Bakery Products], 10, 59-61.

Pankratov, G. N., Meleshkina, E. P., Kandrokov, R. Kh., \& Vitol, I. S. (2016). Tekhnologicheskie svoistva novykh sortov tritikalevoi muki [Technological properties of new varieties of triticale flour]. Khleboprodukty [Bakery Products], 1, 60-62.

Sokol, N. V. (2014). Tritikale - khlebnaya kul'tura [Triticale - grain culture]. Germaniya: Palmarium Academic Pulishing.

Vitol, I. S., Meleshkina, E. P., \& Kandrokov, R. Kh. (2016). Produkty pererabotki zerna tritikale kak ob"ekt dlya fermentativnoi modifikatsii [Grain processing products triticale as an object for enzymatic modification]. Khranenie $i$ pererabotka sel'khozsyr'ya [Storage and Processing of Farm Products], 9, 14-16.

Vitol, I. S., Meleshkina, E. P., Kandrokov, R. Kh., Verezhnikova, I. A., \& Karpilenko, G. P. (2017). Osobennosti biokhimicheskogo sostava tritikalev- oi muki raznykh sortov [Features of the biochemical composition of triticale flour of different varieties]. Khranenie i pererabotka zerna [Storage and Processing of Grain], 2, 30-32.

Vitol, I. S., Meleshkina, E. P., Kandrokov, R. Kh., Verezhnikova, I. A., \& Karpilenko, G. P. (2016). Biokhimicheskaya kharakteristika novykh sortov tritikalevoi muki [Biochemical characteristics of new varieties of triticale flour]. Khleboprodukty [Bread Products], 2, 42-43.

Blum, A. (2014). The abiotic stress response and adaptation of triticale - A review. Cereal Research Communications, 42(3), 359-375. https://doi. org/10.1556/CRC.42.2014.3.1

Bona, L., Acs, E., Lantos, C., Purnhauser, L., Lango, B., \& Tomoskozi, S. (2013). Human utilization of triticale: Technological and features, milling and baking experiments. In: Abstracts 8th international triticale symposium (p. 46). Ghent, Belgium.

Dennett, A. L., Cooper, K. V., \& Trethowan, R. M. (2013). The genotypic and phenotypic interaction of wheat and rye storage proteins in primary triticale. Euphytica, 194, 235-242. https://doi. org/10.1007/s10681-013-0950-y

Dennett, A. L., \& Trethowan, R. M. (2013). The influence of dual-purpose production on triticale grain quality. Cereal Research Communications, 41(3), 448-457. https://doi.org/10.1556/CRC.2013.0022

De Laethauwer, S., Reheul, D., De Riek, J., \& Haesaert, G. (2012). Vp1 expression profiles during kernel development in six genotypes of wheat, triticale and rye. Euphytica, 188, 61-70. https://doi. org/10.1007/s10681-011-0613-9

He, M. L., McAllister, T. A., Hernandez-Calva, L. M., Aalhus, J. L., Dugan, M. E. R, \& McKinnon, J. J. (2014). Effect of dietary inclusion of triticale dried distillers' grain and oilseeds on quality and fatty acid profile of meat from feedlot steers. Meat Science, 97(1), 76-82. https://doi.org/10.1016/j. meatsci.2014.01.008

Kandrokov, R., Pankratov, G., Meleshkina, E., Vitol, I., \& Tulyakov D. (2019). Effective technological scheme for processing triticale grain into high-quality baker's grade flour. Foods and Raw Materials, 7(1), 107-117. https://doi. org/10.21603/2308-4057-2019-1-107-117

Meleshkina, E. P., Pankratov, G. N., Vitol, I. S., Kandrokov, R. H., \& Tulyakov, D. G. (2017). Innovative trends in the development of advanced Triticale grain processing technology. Foods and Raw Materials, 5(2), 70-82. https://doi. org/10.21603/2308-4057-2017-2-70-82 